\title{
機械的手段による 雑草防除
}

\author{
宮崎大学農学部 古 池 寿 夫
}

Toshio Furuchi*: Weed Control by Mechanical Method

\section{1. 期待される総合的除草体系}

雑草防除の手段には耕種的防除法, 機械的防除法, 化 学的防除法, 生物的防除法, 熱等による物理的防除法が あることは周知の通りであるが13)，現在では除草剤を中 心とした化学的防除法が雑草防除手段の主流を占め, 他 の手段は著しくその役割を失なっている。

最近の傾向としては，除草剤の利用を必要以上に過重 評価し，他の手段を顧みることが少なくなり，それが除 草体系を複雑にし，除草効果を不安定にして，栽培技術 全体にひずみすら生じていると思われる。

例えば，水稲直播栽培についてみると，現実にはその 普及があまり進んでいないが，その技術的な主因として は, 出芽が不安定であることと雑草防除を的確かつ能率 的に行う手段が明確でないことが挙げられる。技術指導 方針として示されている水稻直播栽培の現在の除草体系 は, 除草剤が主流となっているが，除草剤に偏った除草 方法では，農家の粗場の場合は，その時の複雑な制約条 件に影響されて期待していた除草効果が得られず，その 結果ばくだいな手取りの除草を必要とする例が極めて多 い。もともと雑草防除を大きな权らいとして行われてき た田植作業を省いて围場に直播した場合には, 雑草防除 には極めて周到な対策が必要である。除草剤のみで完全 除草を期待するのはあまりにも安易なやり方と言うべき であり, 各種の防除手段を適宜に併用した総合的な除草 体系が必要であると考学る。このようなことは他の作物 栽培にも数多くみられよう。

筆者は，今日まで機械的除草手段を基幹とした除草体 系の研究に取り組み, 化学的除草手段については全くの 素人で，除草剤をも含めた総合的除草体系を的確に論ず ることのできる立場にはないが, 以下, 機械的除草の特 性や利用上の問題点および機械的手段を取り入れた除草 体系について考光を述べ，参考に供したい。

\section{2. 機械的除草手段の種類}

機械的除草手段といえば，播種以降に使用される中耕 除草機具を指す場合が一般的であるが，主な使用目的が 除草以外であっても, 除草効果を併せもつものがかなり
多い。ここでは，それらを含めた広義の除草機具=機械 的除草手段を対象とし，その種類を列挙する。

1）耕ら九用機具：これは，次に記す砕土均平用機具 とともに播種や移植のための圃場の準備作業として使用 されるが, 主な最終目標は, 砕土と均平に加え, 前作の 刚株や残存雑草を処理すること, すなわち広義の除草で ある。これには, 人力用としては鍬類, 鋤類が, 歩行 用, 乗用のトラクタには, 毫引耕用としてプラウ, 犁な どが，駆動耕用としてロータリ耕うん機，ロータリプラ ウなどがある。作用深さは $10 \sim 30 \mathrm{~cm}$ であるが，耕深が 大きいほど除草効果は高い。稲作の生産調整による雑草 多発の休閑田の除草対策としては, 除草剤とか中耕除草 機の単用では無理な場合が多く, 耕うん用機具が十分見 直されるべきであろう。

2) 研土均平用機具 人力用としては鍬類, レーキ類 が, トラクタ用にはまぐわ, 八ロー, ディスクハロー, ティラ用の各種ロータ, ロータベータ, ロータリ耕うん 機などがある。作用樑さは $3 \sim 5 \mathrm{~cm}$ である。

3） 中耕除草機具 人力用には鍬類, 万能, ホー, 3 本爪のカルチベータがあるが, 今なお根強い需要があり, また機械除草の補助的役割も大きい。動力用には, 畦内 （株間・株際）用としてウィーダ，八ロー，麦用の跳上 式土入機, 間引機が, 条間用としてティラ用のロータ, ミニカルチ，ロータリ爪，カルチベータなぞがある。

最近我が国では, 湛水田稲作用中耕除草機のミニカル チ（商品名）が急速に普及しつつあるが，これは，国際 稲研究所 (フィリピン) が我が国在来の人力回転除草機 をもとにして動力用に改良したものを，我が国の農機入 一カーが逆輸入して改良を加えたものといわれている。 この例にみられるように, 我が国の在来の除草機具につ いても，時代の流れであるというようなことで簡単に見 捨てることなく, それがもつ機能の長所を現在の機械化 に適用する姿勢が欲しいものである。

4）草刘用機具 人力用として各種の鐮が, 動力用と してトラクタ用および携帯用の回転型モア, 往復刃型モ ア，ロータリカッタがある。

5）その他 他の除草手段の補助的役割を果たす機具 として, 除草剂散布用の噴霧機, 散粒機や, マルチ栽培

* Faculty of Agriculture, Miyazaki University, Miyazaki. 
用のマルチ用フィルム被覆機がある。

\section{3. 機械的手段による除草機能}

おおまかに分けると，基本的な除草作用は次の四つで ある。

i ）プラウや犁のように土塊や壢土を反転し，あるい は培土機や土入機のように土を作物の根際に覆らことに より，雑草種子の出芽を抑制したり雑草の幼苗を枯死さ せる。雑草種子の発生深度は $8 \mathrm{~cm}$ 程度といわれている が，プラウや犁で $12 \sim 30 \mathrm{~cm}$ の深さに耕起して地表面を 反転すると, 地表面や地表近くの雑草種子は発生深度以 下に埋没することになり，雑草の発生は著しく少なくな る。一般に土の反転埋没による除草効果は，後記の他の 除草作用より大きいと評価されている。

ii）土を歯杆などで深さ $2 \sim 5 \mathrm{~cm}$ 撹拌することによ り，雑草の根を土から離したり抜き上げて枯死させる。 これの代表例としてはウィーダの歯杆，カルチベータの 中耕爪，耕らん機やミニカルチのロータリ爪，ハローの 歯杆を挙げることができる。この作用は除草機に広く採 用されており，除草効果はかなり高いが，使用前後に降 雨があり土袞水分の多い場合には，引き抜かれた雑草が 蘇生して除草効果が低下寸る。

iii）雑草の茎部を地表下 $1 \sim 2 \mathrm{~cm}$ で切断して枯死さ せる。これの代表例としては鍬やカルチベータの除草刃 があるが，除草刃は，圑場の凹部では土に作用せず，除 草が行われないため, 除草効果にやや難点がある。な お, 雑草の茥葉部を地表面で切断するものとしては，草 刚機の回転刃や往復刃がある。

iv）刃などで草丈のかなり高い雑草を細かく切りきざ む。これはｉi）の作用を伴ら場合が多い。筆者は，ロー タリ耕らん機（耕うん幅 $60 \mathrm{~cm}$ ）に耕うん爪を市販機の $2 \sim 3$ 倍の 30 50 本取り付け，さらに耕うん軸の回転 数を市販機の 20 3 0 \% 増速し，爪の縦ピッチを最小 $1.5 \mathrm{~cm}$ にして砕土性と株処理性を高めることを試みた が, 草丈が $30 \sim 40 \mathrm{~cm}$ もある雑草でも爪に絡み付くこと がなく, 長さ $3 \sim 4 \mathrm{~cm}$ に裁断されて除草効果を挙げ $た^{1 \sim 4)}$ 。そのほか乗用トラクタ用のロータリカッタも同 様の除草効果がある。これらは休耕田や草生栽培の果樹 園の雑草などの処理に効果的である。

なお，除草機具の多くは，以上の作用を二つ以上備え ている場合が多い。

\section{4. 作業面および経営面からみた機械的 除草手段の得失}

作業面および経営面からみた機械的除草手段の一般的
得失を, 主として化学的除草手段 (除草剂) と比較して 検討してみよら。

i ）機械除草は, 雑草が幼少の時期には, その種類が 異なる場合でも, また草丈, 葉数などの生育段階が幾分 異なっていても，作用部品により画一的に力学的な作用 をする結果, 大体同程度のかなり高い除草効果が得られ る。すなわち非選択性である。例えば，ロータリ爪で播 種後 20 日目に深さ $5 \mathrm{~cm}$ で中耕すれば，どの種類の雑草 も，また草丈が $3 \mathrm{~cm} ， 6 \mathrm{~cm} ， 8 \mathrm{~cm}$ と異なっていても， 爪の回転作用によってほとんどの雑草を除去できる。こ れに対し, 除草剂の除草効果は, 雑草の種類や生育段階 によってかなり異なる。すなわち選択性である。以上の ことから, 機械除草の利用範囲は融通性に富むと言えよ 5 。

ii）耕うん・整地・除草機具は, 前記 3 . のような作 用をするために，除草効果だけでなく，土袞処理効果も 期待できる。除草機具についてその主要例を次に列挙す る。中耕爪やロータリ爪は，除草効果とともに通気性， 透水性の増大といった中耕効果が大きい。最近, 湛水田 稲作の機械除草用としてミニカルチ（商品名）が急速に 普及しているが，これは，湛水状態下の中耕作用で通気 性を高めることにより，コンバイン作業時に残存した稲 わらの分解を促進する効果が大きい。培土板や土入機に よる土寄せ，土入れは，雑草を埋める除草効果だけでな く，作物の倒伏と過唾分げつの防止および簡易排水溝の 役割も果している。水田稲作における培土作業が再び普 及しつつあるが，これは培土機で國場内に排水溝を作る ことにより，2 か月後に行われるコンバイン作業が円滑 に行えることをねらっている。これに対し, 除草剤は単 一の除草効果に限られる場合が多い。

iii）次に土壌水分の条件に対する適用性について比較 する。機械的除草手段では, その作用部品が土に直接作 用するので，降雨後の過湿な圑場では作用部品への土の 付着や車輪のスリップなどにより作業が困難または不能 となり，除草効果も低下するが，乾燥圃場では適用性が 大きい。これに対し除草剤は，土壌処理，茎葉処理と も, 湛水状態では除草効果が高く, むらも少ない。しか し土壌処理で水を媒体とする除草剤では，直場が乾燥し ている場合，特に土塊が大きく鎮圧が不十分な場合には 除草効果が不安定である。すなわち除草剤を水に溶かし た薬液を $10 \mathrm{a}$ 当たり $100 l$ 散布した場合の散水深はわず か $0.1 \mathrm{~mm}$ であるから，土が乾燥している時には十分 な処理層が得られない場合が多い。なお，除草剤散布の 場合は，機具除草のように作用部が土に接し作用するこ とがないので，土壊水分がかなり多くても作業には差し 
支えない。

iv）次に作物の損傷や欠損に対する安全性について検 討する。歩行用および乗用のトラクタに装着する除草機 は，機械の機能から，画一的にまっすぐに進行する作業 形態であるため, 鍬のような前後自在に融通のきく操作 はできない。そのため, 操作がまずいと中耕爪やロータ リ爪が作物に当たって久損や損傷を与えることになる。 従って, 機具の調整と操作にはある程度の習熟が必要で あり, 気疲れも多く, さらに後記するように栽培様式に も工夫を要する。これに対し, 除草剂では機械的作用に よる作物の損傷や欠損はほとんどない。しかし，散布時 期, 前後に使用する農薬の種類, 降雨等の気象条件など により，作物に薬害が発生したり除草効果が減退したり することも多く，この点から利用上の制約をかなり受け ることになる。

v) 畦内 (株間・株際) の除草は, 機具除草では困難: な場合が多い。畦内用の除草機具には, 人力用として熊 手，レーキ，トラクタ用としてウィーダ，土入機がある が, 能率面や除草効果からみた適用性は除草剤には到底 及ばず，畦内除草では除草剤が圧倒的に主流の座を占め ているのが現状である。なお，筆者は，機具除草のこの 分野での弱点を克服するため, 小型トラクタ用ウィーダ の開発研究に取り組み，後記するようにほぼ実用できる 段階に至っている。

vi）次に作業経費の面から検討する。作業経費は機械 利用費, 消耗品費, 労力費から成っている。機械除草の 場合には，機械利用費として乗用または歩行用トラクタ の本機や除草機具の購入にかなり多額を要するのが難点 とされるが, 消耗品費は燃料と潤滑油の購入費程度で少 ない。労力費は，人力除草の場合は多くかかるが，乗用 トラクタでは $10 \mathrm{a} \quad 0.5$ 時閒, 歩行用トラクタでは $10 \mathrm{a}$ $0.5 \sim 1.0$ 時間の能率であるためわずかの労力費で足り る。機械利用費についてみると, 現在の我が国の農家は 高価な乗用トラクタや歩行用トラクタを必要以上に導入 し，機械化貧乏の様相すら呈している。これを改善する 手段として，トラクタの利用を多目的に拡大し利用度を 高める必要性が強調されている。従って, 現在導入され ているトラクタを，除草に主目的をおいた耕うんや機械 除草に利用することは農家経済からみて効果的であり， 大局的には除草経費の低減となろう。

一方，除草剤の場合には，その購入費は比較的安価で あるため消耗品費はそう多くはならない。また機械利用 費も, 人力噴霧機や動力噴霧機を使えば安価であるが, 作業強度が大きく, 能率もやや低いため, 労力費は幾分 高くなろう。また畑での除草剤の散布は, 水が容易に得
られぬとか，薬液の補給に手間取るなじ，作業上の险路 もある。

除草経費は，栽培期間中の全部の除草に要した経費で 比較すべきであることは当然であるが，その場合，特に 機具または除草剤による除草作業の不完全さを手取り除 草で補完したりすると，ばくだいな労力費を要すること になるので, 十分留意しなければならない。かかる見地 から，機具を用いる場合にも除草剂による場合にも初期 除草を完全に行らことが極めて大切であることが首肯さ れよう。

\section{5. 小型トラクタによる畦内除草}

畦内（株間・株際）の除草には，作物は残し雑草は除 去する選択性が求められるが，機械除草は概して非選択 性であるため，この面では大きな難点となる。

前記のように, 筆者らは小型トラクタ用ウィーダによ りこの難点を克服できる見通しを得るに至ったので，以 下これについて説明する。

小型トラクタ用ウィーダ (試作機) の構造は第 1 図の 通りである。牽引は $3 \sim 5$ PS の空冷エンジンを搭載し たティラで行ら。ウィーダの機幅は $50 \sim 60 \mathrm{~cm}$, 長さは $50 \sim 70 \mathrm{~cm}$ であり, 横桁に取り付けた歯杆は, 横間隔, 縦間隔とも約 $10 \mathrm{~cm}$ ，軌跡間隔が $1.7 \mathrm{~cm}$ である。

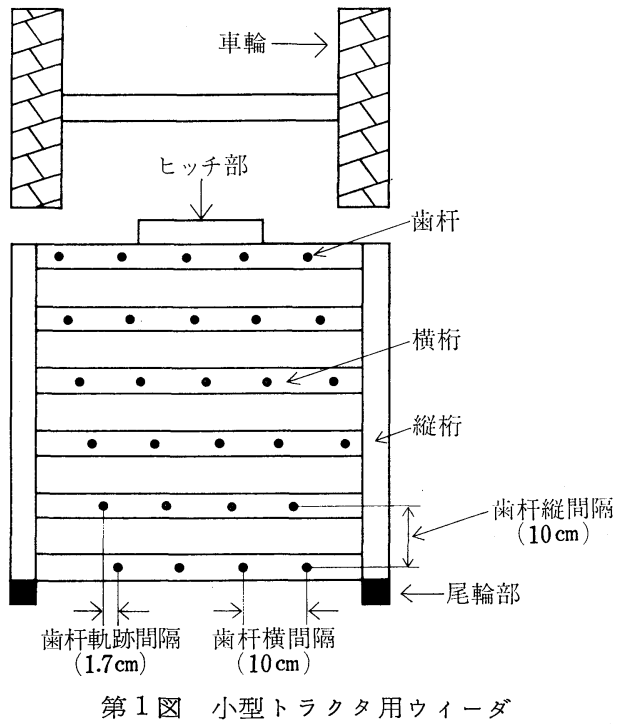

作業能率としては，作業幅 $60 \mathrm{~cm}$ ，作業速度 $0.7 \sim 1.0$ $\mathrm{m} /$ 秒であり, $10 \mathrm{a}$ 当たりの所要時間は 40 60 分とな るから，1 日 ( 8 時間) 1 ha の除草はさほど困難ではな い。筆者らの畨場試験の結果, 適用性が認められた作物 とウィーダの使用時期は，コムギ，八ダカムギは播種直 


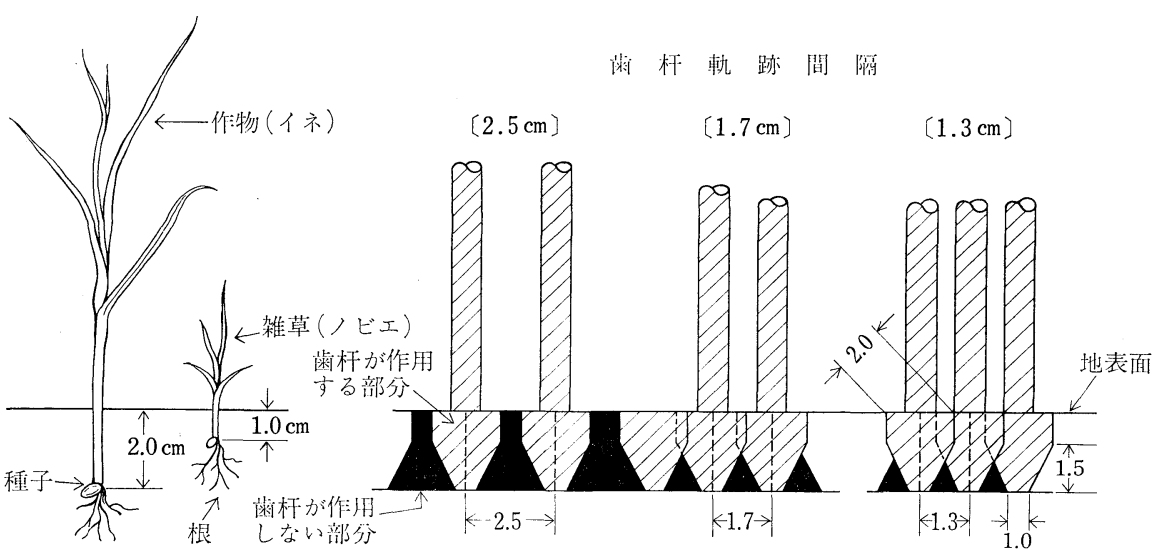

第 2 図 ウィーダ歯杆の作用
として決めるべきで あるが，普通の場合 は $2.5 \mathrm{~cm}$, 種子を 樑く播けるダイズ, ラッカセイでは 3.0 $\mathrm{cm}$ が基準となる。 ウィーダ歯杆をどの 播床に対しても円滑 に, 基準の深さ,例え ば $2.5 \mathrm{~cm}$ でむらな く作用させるには, 播床の表層は $2 \mathrm{~cm}$ 以下の大きさに砕土 され，前作の株処理

後 40 日 ${ }^{5)}$, 乾田直播水稲, 畑水 (陸) 稲は播種直後 30 日 $^{6,7)}$, ラッカセイは播種後 $6 \sim 20$ 日 $^{8)}$, ダイズは播 種後 10 20 日 ${ }^{8)}$, ナタネは播種後 20〜40 日 ${ }^{8)}$, カンショ は挿苗後 15 20 日 ${ }^{8)}$ である。なお，上記の作物以外に イタリアンライグラス，トウモロコシなどにも実用性が あろら。1 回のウィーダ除草による作物の久損率は 2 $5 \%$ ，除草率は 80 90\%である。

ウィーダ歯杆の除草機構9)を第 2 図により簡単 に説明する。第 2 図では，イネは地表下 $2.0 \sim 2.5$ $\mathrm{cm}$ の部位に播種, 覆土されて出芽し, ノビエは地 表下 $1 \mathrm{~cm}$ の部位から出芽しているのに対し, 歯 杆はイネとノビエが共存する畦内（播床）で地表 下 $2.0 \mathrm{~cm}$ の深さまで作用するので，イネは残り ノビェは除去される。.なお, 第 2 図の斜線の部分 は歯杆が通過する部分であり，この部分の土層は 破砕されるため, 雑草は土粒から分離したり切断 されたりして枯死するが, 黒い部分は歯杆が通過 しない部分で, 除草作用は一部分を除き行われな い。イネは歯杆がほとんど作用しない位置（地表 下 2.0〜2.5cm）にあるため，歯杆による久損は ほとんどない。

除草効果を高めるには, 斜線の部分を増大すれ ばよいが，そのためには，歯杆の幅を大きくする こと，歯杆の作用深さを大きくすること，歯杆の 軌跡間隔を小さくすることなどが必要である。し かし歯杆の作用部分を過大にすると作物も欠損す ることになる。一方とれを防ぐために作物の種子 の播き位置を深くすると出芽不能になる恐れがあ る。従って, ウィーダの作用深さは, 作物の種子 が安全に出芽できる覆土深さより媣くならないこ とを前提とし，除草効果も期待できることを目標

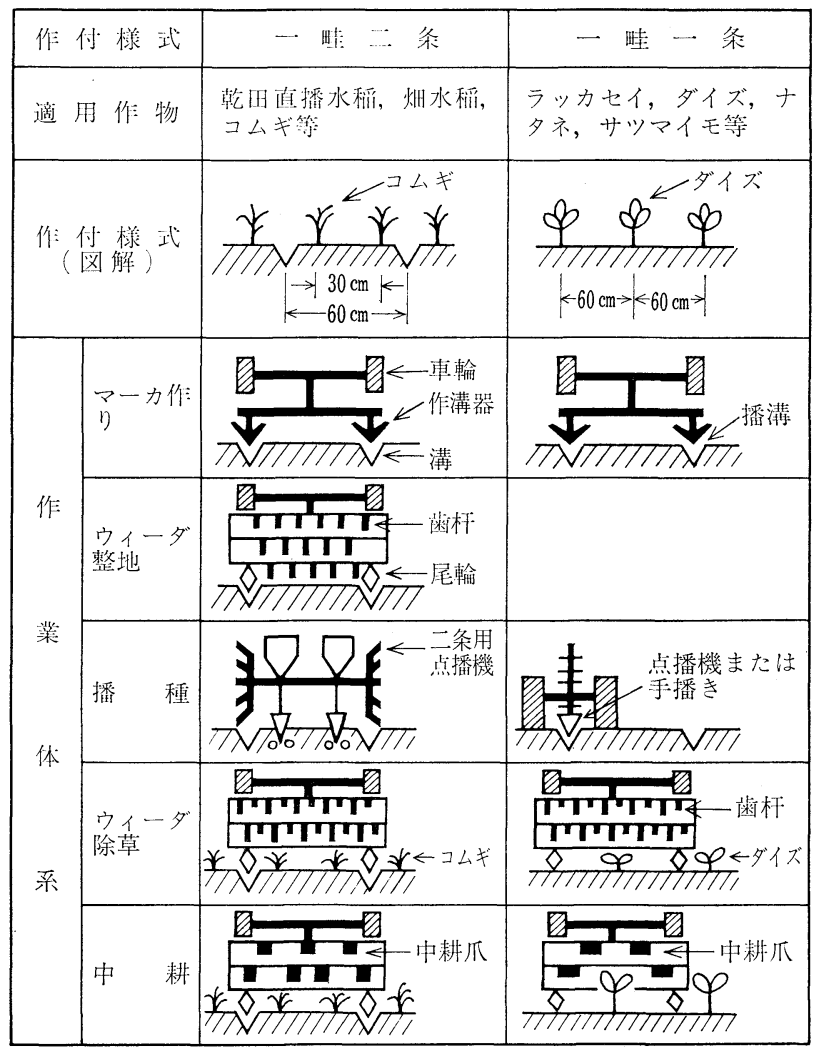

第 3 図 小型トラクタ用ウィーダを基幹とした作業体系 
るのもよい。以上のようにウィーダを円滑に使うために は，前後の作業や栽培様式にも工夫を要する。

第 3 図は，畦幅を $60 \mathrm{~cm}$ とし，一条播きを行ら場合と 二条播きを行う場合のウィーダを基幹とした作業体系の 標準を示したものである。

筆者らが試作した小型トラクタ用ウィーダは, 農家で も自作できる簡単な構造のものであるが，まだ農機メー カーにより市販されるまでには至っていない。一般農家 には，ウィーダは雑草とともに作物をも除去してしまう のではないかといった不安が根強くあるであろらが, 事 実はそのようなものではなく, 今後の開発と普及活動に より普及する日が来ることを期待したい。

\section{6. 機械的手段による除草作業の場合の 留意事項}

i ）トラクタ用の犁やプラウによる反転耕は，3.の i ) で記したように雑草の種子や株や茥葉の埋没効果が 大きいので, 雑草の発生の多い圃場では大いに活用す心゙ きである。特に畑では, 反転耕でも砕土はかなりの程度 まで行われ，作業上の難点が少ないので積極的に導入す べきである。ロータリ耕は, 反転性や埋没性は劣るが砕 土性が高く，3. の iii), iv) で記したよらに砕土と切断 による除草効果もかなり期待でき，またプラウのように 「中高」になるという作業上の難点もないので，水田で は広く用いられ，最近では畑にも普及しつつある。しか しロータリ耕を連用すると雑草が多発化する傾向がある ので， 1 年に 1 回とか 2 年に 1 回は犁耕やプラウ耕を導 入する必要がある。すなわち反転耕と駆動耕（ロータリ 耕）のサイクルを，圑場条件に応じて適当に実施するこ とが検討されなければならない。

ii）播種前や移植前の砕土均平作業による除草効果を 再評価すべきである。

耕起してから播種するまでの期間 (10日〜3 か月) に, 雑草の発生程度を勘案してロータリ爪や歯杆による 砕土均平作業を適当回数 $(2 \sim 4$ 回) 行うと, 雑草は 出芽 $\rightarrow$ 枯死を繰り返し, それぞれの時期に出芽する可能 性のある雑草が播種前にかなりの程度除去されて作物の 生育初期の雑草が著しく少なくなる。このような例とし ては，田植前の代搔きを荒代搔き $\rightarrow$ 中代搔き $\rightarrow$ 植代搔き と，5１0日の期間をあけて行ら慣行があるが，これは 砕土とともに徹底した除草効果をねらったものである。 また筆者が試みた 3 ha の階段状水田における水稲機械 化直播栽培では，耕起から直播までの 2 か月間に湛水 $\rightarrow$ 代搔きい落水を 3 回繰り返してから乾田直播したところ ノビエなどの雑草がほとんど除去された ${ }^{10)} 。$ iii）播種後に行う機具除草は，初期除草，中期除草， 後期除草に分けられる。おおまかな標準としては，初期 除草は，夏作では播種後 20 日まで，冬作では播種後 40 日まで，中期除草は，夏作では播種後 20〜 40日，冬 作では播種後 40 60日，後期除草は，夏作では播種後 40～60 日，冬作では播種後 60～90 日となろ5。一般に 雑草防除では, 初期除草を徹底的に行うことが省力, 低 コスト, 完全除草を達成するための必要条件であるが, このことは機具除草でも強調すべきことである。初期除 草の適期を失し, 中期, 後期の除草に多大な手学働を必 要とした経験を持っている人は少なくないと思われる。 筆者らは, ノビェなどの雑草について, 引き抜き抵抗等 の各種の力学的抵抗值を生育段階ごとに測定調查し, 初 期の抵抗值は中期, 後期のそれに比較して極めて小さ く, 初期雑草の除去に要するエネルギーが極めて小さい ことをあらためて実証した ${ }^{12,13)}$

初期除草には，䍜内用としてはウィーダ，土大機が， 条間用としては中耕爪，ロータリ爪，ミニカルチ等が使 用され，中期・後期除草用にはロータリ爪，中耕爪，培 土板等が使用される。

iv）畦内（株間・株際）の機具除草については次の二 点を強調したい。

(1) 小型トラクタ用ウィーダの利用について：ウィー ダは，5.で記したように，単独で利用した場合でもかな りの除草効果があるが, 雑草の多い圃場では除草剤と併 用することにより除草効果が大幅に高まる。筆者らは水 稲の乾田直播栽培において, ウィーダのみ, 除草剤 DC $\mathrm{PA}$ のみ, ウィーダと DCPA との併用の除草試験を行 ったが7)，播種後 35 日間に「DCPA $\rightarrow$ ウーダ $\rightarrow \mathrm{DCP}$ $\mathrm{A} \rightarrow$ ウーダ」の作業を行うことによって除草率はほぼ $100 \%$ となり， DCPAのみやウィーダのみ（除草率 80 \%) より高い除草効果が得られた。また $3 \sim 5$ 葉期のノ ビエには DCPA 単独の場合は除草効果は期待できない が，DCPAを散布し，その 3 日後にウィーダを深さ 2 $\mathrm{cm}$ で作用させたところ，ノビエは茎や根が切断された り引き抜かれたりして枯死した。これらは除草機具と除 草剂との併用による総合的除草体系の好例といえよう。

(2) 作物の栽培様式と土寄せについて：培土板を用い, 土による雑草の埋没を的確に行うためには，作物の播幅 を $2 \sim 3 \mathrm{~cm}$ に狭くする必要があり, 播種機の作溝器も そのような構造にする。

なお，ムギの広幅播きのように播幅を広くすると，こ の部分の機具除草としては土入機のような複雑な作用と 構造の機具が必要となったり, 手取り除草によらざるを えなくなる。単純な機構の安価な機具によって作業をす 
るためには, このように, 作物の栽培様式に対する若干 の工夫と改善が必要となる。

v）乗用または歩行用のトラクタに装着する除草機を 能率よく使い，しかも高い除草効果を挙げるためには， 围場の排水が良好で，圃場の表層がよく砕土されてお り，固場面が均平であることが望ましく，圃場が過湿の 時には使用を避ける。また栽培様式では，作物の播条は 間隔が均一でまっすぐであること, 播条の間隔（条間） の大きさは，作物に対する作用部分や車輪による損甥を 少なくするため，やや広目の $30 \sim 60 \mathrm{~cm}$ とする。なお， 条間内に走行車輪を入れる場合は，単輪をたは超小型の 管理用ティラに限られ，条間隔は $40 \sim 60 \mathrm{~cm}$ が標準とな る。乗用トラクタでは播条を跨ぐことになり，その場合 の条間隔は $30 \sim 40 \mathrm{~cm}$ が標準となる。

\section{7. あと がき}

作物の各生育段階においていかなる除草手段（機具， 除草剤等）を採用するか，また全体の除草体系や栽培体 系からみてどのよらな除草手段をいかに組み合わせるか については, 除草効果が高く安定していること, 所要労 力が少ないこと，作業経費が少ないこと，作物・人音・ 魚類・土猿環境に対して安全であることを念頭におき， 総合的に検討し，決定すべきであろう。

単一の手段, 例えば除草剤単独とか機具単独により除 草を達成できればそれに越したことはないが, 雑草の発
生が激甚であるとか複雑な様相を呈していて単独の手段 では期待される除草効果が得られぬ場合には，その難点 を補う他の手段を大胆に採用すべきであろう。

ともあれ，地域条件や農家の固場条件に適した機械的 手段, 化学的手段を含めた総合的除草体系の研究と普及 を望みたい。

\section{引用 立 献}

1) 古池寿夫等：口ータリ耕 5 亿機の砕上性能と株処理性能の向上阙 する研究 (第 1 報). 農業機械学会誌 (農機誌) 35 (2), (1973).

2) 古池寿夫等: 同 上 (第 2 報). 農機誌 35 (2), (1973).

3）古池寿夫等：同 上(第 3 報). 農機誌 36 (3), (1974).

4）古池寿夫等：同 上 (第 4 報), 農機誌 36 (3), (1974).

5）古池寿夫等：小型トラクタ用ウィーダに関する研究（第 2 報），小 麦比対する適用性. 農機誌 35 (2), (1973).

6) 古池寿夫等 : 同 上 (第 3 報)，水稲乾田直播栽培に対する適用性 (その 1 ). 濃機誌 36 (1), (1974).

7) 古池寿夫等 : 同 上 (第 4 報), 水稲乾田直播栽培に対与る適用性 (その 2 ). 農機誌 36 (2), (1974)

8）古池寿夫等 : 同 上 (第 5 報), 甘しょ・ラッカセイ・ナタネ・ダ イズに対する適用性. 農機誌 37 (2)，(1975).

9）古池寿夫等：同 上(第 1 報), 試作した小型トラクタ用ウィーダ の負荷特性と葡場表層に及ぼす影響. 農機誌 31 (1), (1969).

10）古池寿夫：階段状水田に和将る水稲直播機械化作業体系に関する研 究. 宮大農研究時報 11, (1965).

11) 御手洗正文・古池寿夫等：作物・雑草の幼苗期に叔ける力学的性質 について (第 2 報), PCPA 除草剛が水稲及び白上ェ・ノビェの幼 苗期の力学的性質飞及ほす影響. 宮大農研究報告 23, (1977).

12）永田雅輝・古池寿夫等：作物・雑草の幼苗期に怙ける力学的性質に ついて (第 1 報), 稲・麦・ナタネ・落花生・メヒシバの幼苗期に 打ける力学的性質について. 宮大農研究報告 23, (1977).

13) 植木邦和 - 松中昭一 : 雑草防除大要. 養賢堂, 東京, $74 \sim 88$ (1972).

(1978 年 3 月 22 日受理) 